\title{
ELEMENTE ALE ARHITECTURII POPULARE ROMÂNEȘTI CARE CRESC EFICIENŢA ENERGETICĂ A CASELOR DIN PĂMÂNT
}

\author{
ELEMENTS OF TRADITIONAL ROMANIAN \\ ARCHITECTURE THAT INCREASE ENERGY EFFICIENCY \\ IN HOUSES BUILD WITH EARTH
}

asist dr. arh./assist. PhD arch. Valerica Potenchi

Universitatea de arhitectură și urbanism „Ion Mincu” București

University of Architecture and Urbanism ,Ion Mincu” Bucharest

potenchi@yahoo.com 



\title{
Rezumat
}

În ultimii ani specialiștii din toată lumea, atât arhitecți cât și ingineri, caută soluții noi pentru realizarea unor clădiri care să răspundă noilor norme ce privesc performanța energetică a construcțiilor. Ținta este realizarea clădirilor cu consum de energie cât mai mic, acest lucru realizându-se prin reducerea pierderilor de căldură și folosirea unor sisteme care să acumuleze căldura solară.

Un exemplu bun în acest sens este arhitectura populară din România care trecând de-a lungul timpului prin diverse transformări a ajuns în forma actuală care răspunde foarte bine condițiilor climatice din această zonă. Pe teritoriul țării noastre clima variază în funcție de altitudine, deosebindu-se astfel trei zone climatice: de munte, de deal și de câmpie. Din acest motiv materialele de construcție tradiționale diferă de la o zonă la alta, observându-se în zonele de deal și de câmpie preferința pentru folosirea pământului ca material de construire. Totodată, casele realizate într-una din cele patru tehnici tradiționale de construire cu pământ (chirpici, lut, pământ bătătorit, paiantă) sunt mai des întâlnite în zonele de sud și sud-est a țării, acestea fiind potrivite climei din această regiune unde verile sunt foarte călduroase şi iernile geroase.

Dacă studiem cu atenție casele construite cu pământ vom observa elemente pe care meșterul popular le-a creat și le-a transformat în timp pe baza experiențelor acumulate pentru a îmbunătății climatul interior al caselor. În acest sens observăm următoarele elemente: grosimea pereților realizați în tehnicile de construire cu pământ, orientarea faţă de punctele cardinale, raportul dintre zonele vitrate și cele opace, folosirea masei termice crescute a pământului pentru încălzirea spațiului interior, dimensiunea streșinilor, amplasarea funcțiunilor.

Cuvinte cheie: chirpici, lut, pământ bătătorit, paiantă, performanță energetică, tradițional, arhitectura populară

\begin{abstract}
In the last few years, specialists from all over the world, both architects and engineers, are looking for new solutions to build buildings that meet the latest performance standards for buildings. The goal to achieve are buildings with low energy consumption, this being done by reducing heat losses and by using systems that accumulate solar heat.

A good example of this is traditional architecture in Romania which, over time, through various transformations has reached a configuration that responds very well to local climatic conditions. On the territory of our country the climate varies according to altitude, thus distinguishing three climatic zones: mountain, hill and plain. For this reason, traditional building materials vary from one area to another, with preference for earth used as building material mainly in hillside and plain areas. At the same time, the houses made in one of the four traditional earthbuilding techniques (adobe bricks, cob, rammed earth, wattle and daub) are more common in the southern and south-eastern parts of the country, suitable for very hot summers and very cold winters.

If we study carefully the houses built with earth, we will observe elements the craftsmen have created and transformed over time that improve the indoor climate of the houses. In this regard, we can see the following elements: the thickness of the walls, the orientation towards the cardinal points, the ratio between windows and walls, the use of the thermal mass of earth for heating the inner space, the size of eaves, the location of the rooms.
\end{abstract}

Keywords: adobe bricks, cob, rammed earth, wattle and daub, energy performance, traditional architecture 


\section{Introducere}

De-a lungul timpului țăranul român a construit case din pământ de la cele mai simple până la cele mai complicate. Privind cu atenție casele tradiţionale de pe teritoriul României vom observa că acestea prezintă elemente comune care sunt rezultatul experienței acumulate în sute de ani de încercări. Așa cum au arătat specialiștii, arhitectura populară românească s-a format de-a lungul timpului încercând de fiecare dată, cu îmbunătățiri, să răspundă condițiilor climatice din această zonă.

Casele populare românești, realizate din pământ, sunt un exemplu bun pentru construcția de clădiri cu consum redus de energie.

Performanța energetică a clădirilor se determină în funcție de mai mulți parametrii care corespund unui calcul de consum energetic necesar pentru a răspunde confortului utilizatorului din mai multe puncte de vedere: încălzire, răcire, ventilare și iluminat.

Pentru realizarea acestui calcul sunt deosebit de importante atât elementele externe cum ar fi: climă, vânt, puncte cardinale, clădiri învecinate, cât și elemente ce aparțin clădirii cum ar fi: structura anvelopei, forma clădirii, materiale de construire, surse proprii de producere a energiei, climat interior.

Din acest punct de vedere sunt o serie de elemente ale arhitecturii populare românești care pot fi preluate și adaptate în proiectarea construcțiilor noi, astfel încât să crească performanța energetică a acestora.

\section{Grosimea pereților realizați în tehnicile tradiționale de construire cu}

\section{pământ}

Casele tradiţionale din chirpici sunt răcoroase pe timpul verii datorită faptului că au pereții groși de aproximativ $40 \mathrm{~cm}-60 \mathrm{~cm}$ și materialul folosit la realizarea pereților conține un procent mare de paie ${ }^{1}$.

Rezistența termică a anvelopei variază în funcție de grosimea anvelopei, respectiv a straturilor ce alcătuiesc anvelopa, materialele folosite și tehnica de construire.

Formula generală pentru calculul rezistenței termice a peretelui exterior este:

$$
\mathrm{R}=\mathrm{R}_{\mathrm{i}}+\mathrm{R}_{\mathrm{e}}+\sum \mathrm{R}_{\mathrm{k}}
$$

unde

$R_{i}$ - rezistenţa termică a suprafeţei interioare $R i=0,125 \mathrm{~m}^{2} \mathrm{~K} / \mathrm{W}$

$R_{e}$ - rezistenţa termică a suprafeţei exterioare $\quad R e=0,042 \mathrm{~m}^{2} \mathrm{~K} / \mathrm{W}$

$\sum \mathrm{R}_{\mathrm{k}}$ - suma rezistenţelor termice a fiecărui strat al peretelui exterior

Rezistenţa termică a fiecărui strat k este:

$$
\mathrm{R}_{\mathrm{k}}=\mathrm{d}_{\mathrm{k}} / \lambda_{\mathrm{k}} \quad\left[\mathrm{m}^{2} \mathrm{~K} / \mathrm{W}\right]
$$

\footnotetext{
${ }^{1}$ Ionescu, G. (1957). Arhitectura populară românească. București:Editura Tehnică, p. 50.
} 


\section{Introduction}

Over time, the Romanian peasant has built homes from the simplest to the most complicated. Looking closely at the traditional houses on the Romanian territory, we will notice that they present common features as a result of accumulated experience over centuries of attempts. As specialists have demonstrated, Romanian traditional architecture took shape gradually, by trying to respond to local climatic conditions, and improving the techniques over time.

Romanian traditional houses made of earth are a good example for the construction of low-energy buildings.

The energy performance of buildings is determined by several parameters that correspond to a calculation of the energy consumption required to respond to user comfort from several points of view: heating, cooling, ventilation and lighting.

To make this calculation, external elements such as climate, wind, cardinal points, neighboring buildings, are important. Building features such as: the envelope, the shape, the materials used, internal sources of energy production and indoor climate also matter.

From this point of view there are a number of elements of the Romanian traditional architecture that can be taken over and adapted in the design of new constructions so as to increase their energy performance.

\section{Thickness of walls made in traditional building techniques with earth}

Traditional adobe bricks houses are cool in summer due to the fact that they have walls about $40 \mathrm{~cm}-60 \mathrm{~cm}$ thick, and the material used to make the walls contains a high percentage of straw ${ }^{2}$.

The thermal resistance of the envelope depends on its thickness, its layers, the materials used and the construction technique.

The general formula for calculating the thermal resistance of the outer wall is:

$\mathrm{R}=\mathrm{R}_{\mathrm{i}}+\mathrm{R}_{\mathrm{e}}+\sum \mathrm{R}_{\mathrm{k}}$

where

$\mathrm{R}_{\mathrm{i}}$ - thermal resistance of the inner surface $\mathrm{Ri}=0,125 \mathrm{~m}^{2} \mathrm{~K} / \mathrm{W}$

$\mathrm{R}_{\mathrm{e}}$ - thermal resistance of the outer surface $\mathrm{Re}=0,042 \mathrm{~m}^{2} \mathrm{~K} / \mathrm{W}$

$\sum \mathrm{R}_{\mathrm{k}}$ - the sum of the thermal resistances of each layer of the outer wall

The thermal resistance of each layer $\mathrm{k}$ is:

$\mathrm{R}_{\mathrm{k}}=\mathrm{d}_{\mathrm{k}} / \lambda_{\mathrm{k}} \quad\left[\mathrm{m}^{2} \mathrm{~K} / \mathrm{W}\right]$

${ }^{2}$ Ionescu, G. (1957). Arhitectura populară românească. Bucureşti: Editura Tehnică, p. 50. 
unde

$$
\begin{aligned}
& \mathrm{d}_{\mathrm{k}} \text { - grosimea stratului } \mathrm{k} \quad[\mathrm{m}] \\
& \lambda_{\mathrm{k}} \text { - conductivitatea termica a stratului } \mathrm{k} \quad[\mathrm{W} / \mathrm{mK}]
\end{aligned}
$$

În cazul construcțiilor din pământ rezistența termică a anvelopei este determinată de compoziția materialului folosit la realizarea pereților. În funcție de tehnica de construire cu pământ (chirpici, lut, pământ bătătorit sau paiantă) variază atât compoziția materialului cât și grosimea peretelui. Materialul folosit la realizarea construcțiilor din pământ este un amestec de argilă, pietriș și praf la care se adaugă paie sau alte materiale care îmbunătățesc calitățile termice ale materialului. Astfel, conductivitatea termică variază în funcție de compoziția materialului, o densitate mai mică a acestuia corespunde unei valori scăzute a conductivității termice (Fig. 1).

Pentru calculul rezistenței termice a pereților care sunt realizați din chirpici putem considera valoarea medie a conductivității termice $\lambda=0,60 \mathrm{~W} / \mathrm{mk}$ stabilit pentru o cărămidă cu densitatea $\rho=1400 \mathrm{~kg} / \mathrm{m}^{3}$, considerând că materialul conține o cantitate medie de paie ${ }^{3}$.

$$
\mathrm{R}_{\text {chirpici }}=0,125+0,042+\mathrm{d} / 0,60
$$
$\mathrm{m}^{2} \mathrm{~K} / \mathrm{W}$

Dar, conform normativului ${ }^{4} \mathrm{C} 107 / 3$, rezistența peretelui exterior trebuie să fie minim 1,8

$$
\begin{aligned}
& R_{\text {chirpici }}>1,8 \mathrm{~m}^{2} \mathrm{~K} / \mathrm{W} \\
& 0,125+0,042+\mathrm{d} / 0,60>1,8 \mathrm{~m}^{2} \mathrm{~K} / \mathrm{W} \Rightarrow \mathrm{d}>(1,8-0,167) \times 0,6 \\
& \text { Deci } \mathrm{d}>0,98 \mathrm{~m}
\end{aligned}
$$

Pentru a respecta normativele în vigoare, peretele exterior realizat din chirpici trebuie să aibă grosimea de aproape $1 \mathrm{~m}$. Dacă în trecut pereții de $60 \mathrm{~cm}$ ai caselor de pământ erau suficienți din punct de vedere termic, azi, în condițiile încălzirii globale, este necesară adăugarea unui strat termoizolant.

Calculul rezistenței termice a pereților care sunt realizaţi din chirpici + strat termoizolant din cânepă:

$$
\begin{aligned}
\mathrm{d}=60 \mathrm{~cm} & =0,60 \mathrm{~m} \\
\lambda_{\text {chirpici }} & =0,60 \mathrm{~W} / \mathrm{mK} \\
\lambda_{\text {cânepă }} & =0,04 \mathrm{~W} / \mathrm{mK} \\
\mathrm{R}_{\text {min }}^{\prime} & =1,8 \mathrm{~m}^{2} \mathrm{~K} / \mathrm{W} \text { conform } \mathrm{C} 107 / 3 \\
\mathrm{R}^{\prime}{ }_{\text {ext }} & =\left(0,125+0,042+\mathrm{R}_{\text {chirpici }}+\mathrm{R}_{\text {cânepă }}\right) \times 1= \\
& =(0,167+0,60 / 0,60+x / 0,04) \times 0,8= \\
& =(0,167+1+x / 0,04) \times 0,8=(1,167+x / 0,04) \times 0,8
\end{aligned}
$$

\footnotetext{
${ }^{3}$ Hajer Milena, Lehmbau-Funktion und Ästhetik Eine Besondere Lernleisung mit den Schwerpunkten Kunst / Biologie, http://milena.hajer.com/\#deutschland

${ }^{4} \mathrm{C} 107 / 3$, Normativ de calcul termotehnic al elementelor de construcţie ale clădirilor
} 
where

$$
\begin{aligned}
& \mathrm{d}_{\mathrm{k}} \text { - thickness of layer } \mathrm{k} \quad[\mathrm{m}] \\
& \lambda_{\mathrm{k}} \text { - thermal conductivity of layer } \mathrm{k} \quad[\mathrm{W} / \mathrm{mK}]
\end{aligned}
$$

In the case of earth made constructions, the thermal resistance of the envelope is determined by the composition of the material used to make the walls. Depending on the building technique with earth (adobe bricks, cob, rammed earth), the composition of the material and the thickness of the wall will vary. The material used to make the walls is a mixture of clay, gravel and dust plus straw or other materials that improve the thermal qualities of the material. Thus, the thermal conductivity varies according to composition, a lower density corresponds to lower thermal conductivity (Fig. 1)

For the calculation of the thermal resistance of the walls made from adobe bricks we can consider the average thermal conductivity $\lambda=0,60 \mathrm{~W} / \mathrm{mk}$ set for a brick with density $\rho=1400$ $\mathrm{kg} / \mathrm{m} 3$, considering that the material contains an average amount of straw ${ }^{5}$.

$$
\mathrm{R}_{\text {adobe bricks }}=0,125+0,042+\mathrm{d} / 0,60
$$

But, according to the norm ${ }^{6} \mathrm{C} 107 / 3$, the thermal resistance of the outer walls has to be $1,8 \mathrm{~m}^{2} \mathrm{~K} / \mathrm{W}$

$$
\begin{aligned}
& \mathrm{R}_{\text {adobe bricks }}>1,8 \mathrm{~m}^{2} \mathrm{~K} / \mathrm{W} \\
& 0,125+0,042+\mathrm{d} / 0,60>1,8 \mathrm{~m}^{2} \mathrm{~K} / \mathrm{W} \Rightarrow \mathrm{d}>(1,8-0,167) \times 0,6
\end{aligned}
$$

So, $\mathrm{d}>0,98 \mathrm{~m}$

In order to comply with the norms in force, the exterior wall made of adobe bricks must have a thickness of about $1 \mathrm{~m}$. If, in the past, the $60 \mathrm{~cm}$ thick earth made walls were thermally sufficient, today it is necessary to add an additional insulation layer.

Calculation of the thermal resistance of the walls made of adobe bricks + hemp insulation layer:

$$
\begin{aligned}
& \mathrm{d}=60 \mathrm{~cm}=0,60 \mathrm{~m} \\
& \begin{aligned}
\lambda_{\text {adobe bricks }}=0,60 \mathrm{~W} / \mathrm{mK} \\
\lambda_{\text {hemp }}=0,04 \mathrm{~W} / \mathrm{mK}
\end{aligned} \\
& \begin{aligned}
\mathrm{R}^{\prime}{ }_{\text {min }} & =1,8 \mathrm{~m}^{2} \mathrm{~K} / \mathrm{W} \text { conform } \mathrm{C} 107 / 3 \\
\mathrm{R}^{\prime} \text { ext }^{\prime} & =\left(0,125+0,042+\mathrm{R}_{\text {adobe brick }}+\mathrm{R}_{\text {hemp }}\right) \times 1= \\
& =(0,167+0,60 / 0,60+x / 0,04) \times 0,8= \\
& =(0,167+1+x / 0,04) \times 0,8=(1,167+x / 0,04) \times 0,8
\end{aligned}
\end{aligned}
$$

\footnotetext{
${ }^{5}$ Hajer Milena, Lehmbau-Funktion und Ästhetik Eine Besondere Lernleisung mit den Schwerpunkten Kunst / Biologie, http://milena.hajer.com/\#deutschland

${ }^{6} \mathrm{C} 107 / 3$, Normativ de calcul termotehnic al elementelor de construcţie ale clădirilor
} 


$$
\begin{aligned}
& \mathrm{R}^{\prime}{ }_{\text {ext }}>1,8 \mathrm{~m}^{2} \mathrm{~K} / \mathrm{W} \\
& \Rightarrow x>(1,8 / 0,8-1,167) \times 0,04=0,043 \mathrm{~m}
\end{aligned}
$$

În concluzie, pentru a răspunde noilor cerințe energetice, la pereții exteriori de $60 \mathrm{~cm}$ grosime ai caselor realizate din chirpici, trebuie adăugat un strat termoizolant de $4 \mathrm{~cm}$. Se recomandă folosirea unor panouri ecologice din cânepă, bumbac sau in care permit structurii de chirpici să respire.

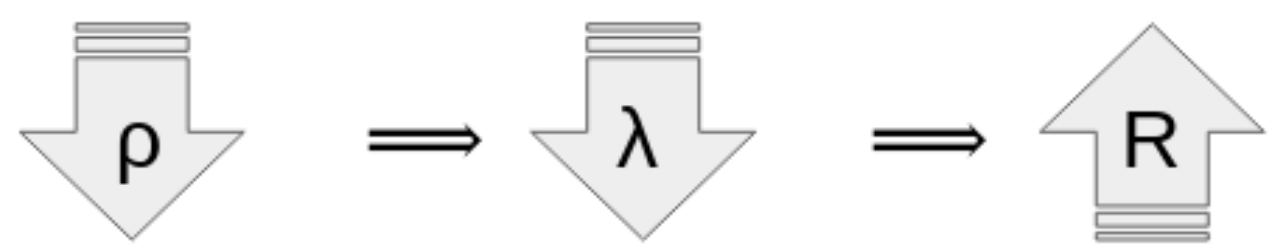

Fig. 1: Rezistența termică a peretelui este invers proportională cu conductivitatea termică și densitatea materialului din care este realizat peretele.

The thermal resistance of the wall is inversely proportional to the thermal conductivity and density of the material from which the wall is made.

\section{Orientarea față de punctele cardinale}

Dacă studiem cu atenție arhitectura populară din România, vom observa că amplasarea caselor țărănești nu este întâmplătoare. Bineînțeles că majoritatea caselor sunt orientate în primul rând către stradă pentru a se realiza ușor accesul în casă. Observăm totuşi că la fel de important este și al doilea principiu de amplasare a caselor. Acestea sunt poziționate în funcție de punctele cardinale (Fig. 2), astfel încât se evită zona de nord, nord-est, est pentru ferestre și accesul în clădire. Sunt mai multe motive pentru alegerea acestei orientări.

Vântul predominant în zona de sud-est a țării este crivățul care bate din direcția nord-est și est, cu precădere în timpul iernii când se constată intensificări puternice ce pot ajunge la viteze de peste $120 \mathrm{~km} / \mathrm{h}$, producând viscolul și temperaturi scăzute.

În același timp fațadele orientate către sud-est, sud și vest au ferestre obținându-se astfel iluminarea naturală a spațiilor interioare și totodată permit acumularea căldurii pe timpul iernii, contribuind la încălzirea spaţiului interior pe perioada în care temperatura exterioară este scăzută.

Principii similare de proiectare pot fi exemplificate cu ajutorul cladirii Druk White Lotus School, Shey, Ladakh, din India. Planul ansamblului fiind rotit fată de punctele cardinale cu $30^{\circ}$ spre est astfel încât sălile de curs sunt orientate către sud-est pentru a avea soare în timpul dimineții atunci când se desfășoară activitatea în această zonă. Corpurile de locuit, unde au fost amplasați pereții Trombe, sunt orientate spre sud-vest acumulând căldura solară. 


$$
\begin{aligned}
& \mathrm{R}^{\prime}{ }_{\text {ext }}>1,8 \mathrm{~m}^{2} \mathrm{~K} / \mathrm{W} \\
& \Rightarrow x>(1,8 / 0,8-1,167) \times 0,04=0,043 \mathrm{~m}
\end{aligned}
$$

In conclusion, in order to meet the new energy requirements, a $4 \mathrm{~cm}$ thermal insulation layer should be added to the $60 \mathrm{~cm}$ thick exterior walls of the houses made of adobe bricks. It is recommended to use ecological panels made of hemp, cotton, or flax that allow the wall to "breathe".

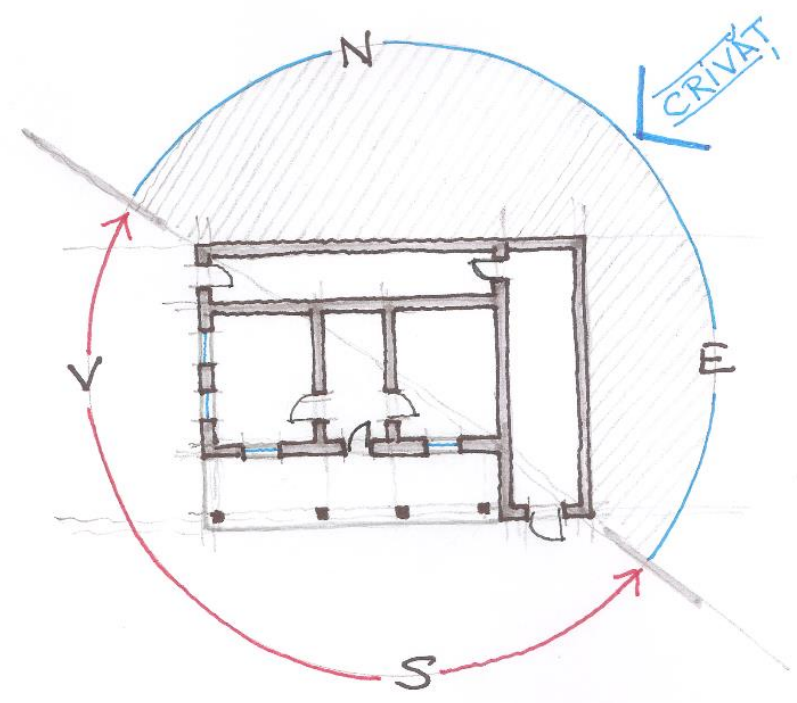

Fig. 2: Ferestrele sunt amplasate pe laturile orintate către vest, sud, sud-est; pereții de la nord și est trebuie protejaţi.

The windows are located on the west, south, southeast sides; the northern and eastern walls must be protected.

\section{Orientation towards cardinal points}

If we carefully study the Romanian architecture, we will notice that the placement of the peasant houses is not a coincidence. Of course, most homes are primarily oriented towards the street to make home access easy. However, we also notice that the second principle of house layout is equally important. They are positioned according to the cardinal points (Fig. 2), so it avoids the north, north-east, east for windows and entrance. There are several reasons for this guideline.

The predominant wind in the southeastern part of the country is the "crivăț" that blows from northeast and east; in winter when strong intensities are reached it can reach speeds above $120 \mathrm{~km} / \mathrm{h}$, producing snow storms and low temperatures.

At the same time, the south-east, south and west facades have windows, thus enhancing the natural illumination of the interior spaces, while also allowing the heat to accumulate during the winter, contributing to the warming of the interior space when outside temperatures are low.

Similar design principles can be exemplified with the Druk White Lotus School, Shey, Ladakh, India. The plan of the ensemble is rotated to the 30 degrees to the east, so the course halls are oriented to the southeast to have sun in the morning when. The living quarters, equipped with Trombe walls, are oriented to the southwest allowing the accumulation of solar heat. 


\section{Raportul dintre zonele vitrate și cele opace}

Casele tradiționale au ferestre mici astfel încât iluminatul natural să fie suficient dar pierderile de căldură prin zona vitrată să fie minime.

Foarte important este raportul dintre zonele vitrate și cele opace ale clădirilor. Zonele vitrate, chiar și cele mai performante au rezistență termică mai mică decât pereții casei. Din acest motiv este de preferat ca ferestrele să fie cât mai mici în raport cu suprafaţa pereților.

În același timp, zonele vitrate fac posibilă folosirea căldurii solare pentru încălzirea construcției pe timpul sezonului rece, perioadă în care, în România, temperaturile maxime medii anuale se situează între $-3^{\circ} \mathrm{C}$ și $-5^{\circ} \mathrm{C}$, iar minima record înregistrată a fost de $38.5^{\circ} \mathrm{C}$. Astfel, ferestrele ar trebui amplasate în așa fel încât razele solare să încălzească zona vitrată în timpul iernii dar vara să fie umbrită.

\section{Folosirea masei termice crescute a pământului pentru încălzirea spațiului}

\section{interior}

Pământul ca material de construire este ideal pentru acumularea căldurii în pereții caselor. Acesta este un material cu capacitate mare de înmagazinare a căldurii pe care o eliberează treptat în perioada rece din timpul nopții.

Căldura specifică a materialelor folosite în tehnicile de construire cu pămant variază în funcție de densitatea materialului de la $1350 \mathrm{~kJ} / \mathrm{kgK}$ pentru materialele cu densitatea $\rho=1500$ $\mathrm{kg} / \mathrm{m}^{3}$ pană la $1800 \mathrm{~kJ} / \mathrm{kgK}$ pentru cele cu densitatea $\rho=2000 \mathrm{~kg} / \mathrm{m}^{3}$.

Sistemul cu perete Trombe (Error! Reference source not found.) se bazează pe capacitatea materialului de acumulare a căldurii solare. Acest sistem constă în realizarea unui perete dintr-un material cu masă termică ridicată în spatele unei zone vitrate, astfel încât razele solare trec prin sticlă și încălzesc peretele care acumulează căldura. Un sistem reglabil de clapete lasă să treacă căldura acumulată peste zi în spațiul dintre perete și sticlă, spre camera învecinată încălzind astfel spațiul interior adiacent.

Un alt exemplu de folosire a capacităţii de înmagazinare a căldurii este alăturarea unui obiect de mobilier din pământ cu o sobă sau vatră.

În satul Letea din Delta Dunării am avut ocazia să vizitez o casă din paiantă renovată, dar în care proprietarii au păstrat sistemele tradiţionale de încălzire (Fig.). În acest scop patul din această casă conține un sistem de canale care comunică direct cu vatra. Acesta este coborâtă sub nivelul pardoselii astfel încât aerul cald este tras prin sistemul de canale care se dezvoltă în lateral, dar la un nivel superior vetrei. Astfel soclul de lut al patului acumulează căldura pe care o eliberează apoi treptat pe timpul nopții.

Pe același principiu funcționează canapelele moderne din lut care se realizează în legătură directă cu sursa de căldură (Fig. 5).

Și pereții casei pot fi încălziți pe baza aceluiași sistem. În acest caz construcția trebuie sa aibă pereții mai groși astfel încât să poată fi integrată rețeaua de canale. Aerul cald provenit din sobe sau alte surse de căldură urcă prin perete încălzindu-l. Peretele din pământ acumulează căldura pe toată suprafața lui, devenind mai târziu o sursă de căldură. 


\section{The ratio between the surface of the windows and the surface of the walls}

Traditional homes have small windows so that natural lighting is enough, but the heat loss through the glazed surface is minimal.

Very important is the ratio between windows and walls of buildings. Windows, even the most modern ones, have lower thermal resistance than the walls. For this reason it is preferable that the windows are as small as possible in relation to the wall surface.

At the same time, windows make it possible to use the solar rays to heat the building in the cold season, during which, in Romania, the average annual average temperatures are between $-3^{\circ} \mathrm{C}$ and $-5^{\circ} \mathrm{C}$, and the minimum record was $-38.5^{\circ} \mathrm{C}$. Thus, the windows should be located in such a way that the sun rays shine through the windows in winter, but are shaded during summer.

\section{Using the thermal mass of earth to heat the interior space}

The earth as a building material is ideal for the accumulation of heat in the walls of the houses. This is a large heat storage that is released gradually during the night in the cold season.

The specific heat of the materials used in earth-building techniques varies with material density from $1350 \mathrm{~kJ} / \mathrm{kgK}$ for materials with density $\rho=1500 \mathrm{~kg} / \mathrm{m}^{3}$ up to $1800 \mathrm{~kJ} / \mathrm{kgK}$ for those with density $\rho=2000 \mathrm{~kg} / \mathrm{m}^{3}$.

The Trombe Wall System is based on the capacity of solar heat storage. This system consists in making a wall of a high thermal mass material behind a glazed area so that the sun rays pass through the glass on the wall that accumulates heat. An adjustable flap system lets the heat accumulated over the day to pass through to the adjoining room, thus heating the adjacent interior space.

Another example of using heat storage is to join a piece of furniture made of clay with a stove or fireplace.

In the village of Letea in the Danube Delta I had the opportunity to visit a refurbished house, but where the owners kept the traditional heating systems (Fig. 4). For this purpose, the bed in this house contains a channel system that communicates directly with the stove. It is lowered below the floor so that warm air is drawn through the channel system that develops laterally at a higher level of the fireplace. Thus, the clay of witch the bed is made accumulates the heat and then gradually releases it during the night.

On the same principle, modern clay sofas work in direct connection with the heat source (Fig. 5).

The walls of a house can be heated with the same system. In this case, the construction must have thicker walls so that a channel network can be integrated. Hot air from stoves or other heat sources climbs through the wall warming it. The wall of earth accumulates the heat on its entire surface, becoming later a source of heat. 


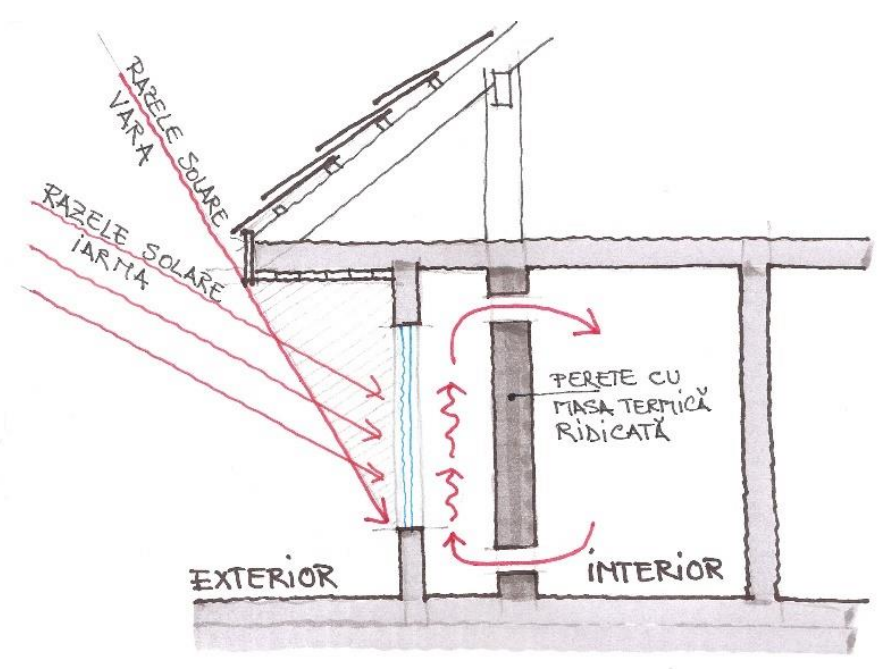

Fig. 3: Perete Trombe. În timpul verii zona vitrată este umbrită, în timpul ienii razele solare trec prin sticlă și încălzesc spațiul dintre peretele vitrat și peretele cu masă termică ridicată. Seara, când temperature exterioară scade, se acționează cele două clapetele mobile permițând auerului cald să treacă în spațiul interior.

Trombe wall. During the summer, the glazed area is shaded, in winter sunlight passes through the glass and heats the space between the the wall with a high thermal mass. In the evening, when the outside temperature decreases, the two movable flaps are activated, allowing the hot air to pass into the interior space.

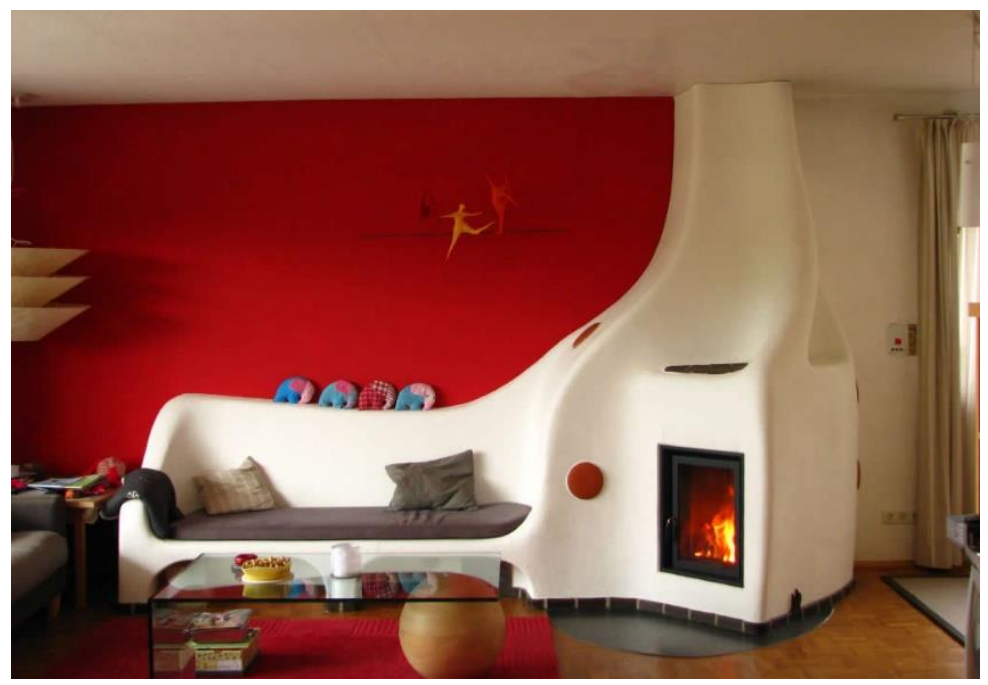

Fig. 5: Varianta modernă a mobilierului din lut în directă legatură cu sursa de căldură. ${ }^{7}$ Modern version of clay sofa connected with a fireplace.

\section{Streșini largi, prispa, foişorul}

În general casele tradiționale au acoperișuri cu streșini largi care protejează pereții casei. Acoperișurile se extind mai ales pe lătura pe care se află accesul în casă, acoperind prispa, în cazul caselor de la câmpie, sau foișorul ${ }^{8}$, în cazul caselor din zona de deal. Prispa și foișorul, sunt elementele care fac legătura dintre spațiul interior și spațiul exterior, fiind o zona de tranziție (Fig. 6).

${ }^{7}$ Lehmundfeuer,http://www.lehmundfeuer.de/lehmundfeuer2.0/blog/2013/01/26/bildergalerie-projektespeicherofen/

${ }^{8}$ Stănculescu FL., Gheorghiu Ad., Stahl P., Petrescu P. (1957). Arhitectura populară românească. Regiunea Ploești. București:Editura Tehnică, p. 15-18. 


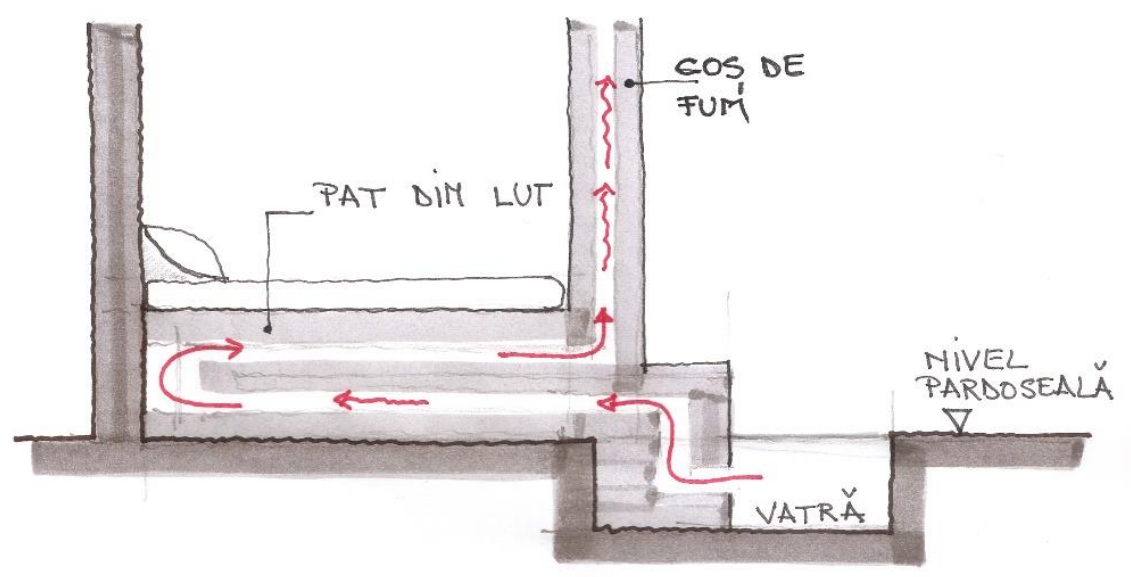

Fig. 4: Sistem tradițional de încălzire, într-o casă din paiantă din Dobrogea, satul Letea. Traditional heating systém Letea village in the Danube Delta

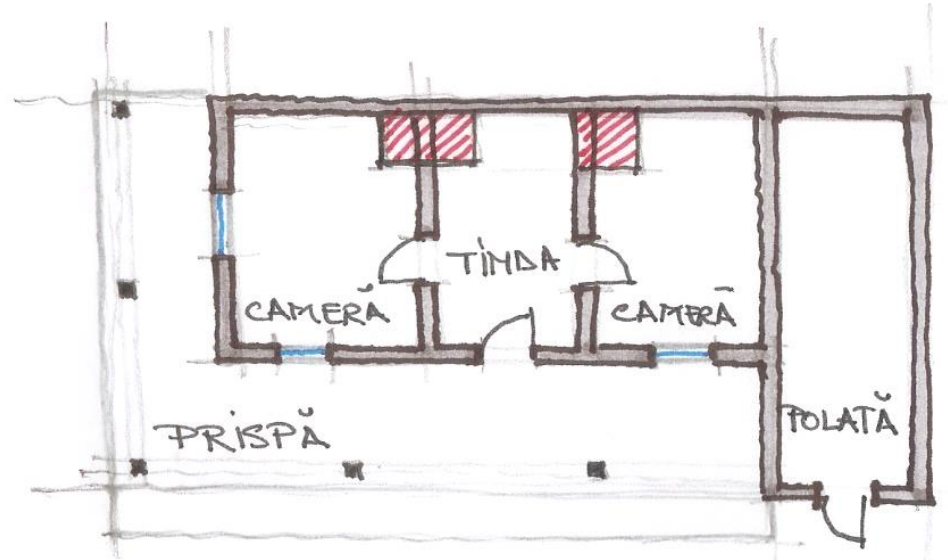

Fig. 6: Planul unei case din pământ cu prispă și polată.

Planof a house with porch (prispă) and storage room (polată).

\section{Large eaves, the porch, the tower}

Traditional houses have large eaves that protect the walls of the house. The roofs extend mainly on the doorway to the house, covering the porch, in the case of houses in the plane area, or a small tower ${ }^{9}$, in the hillside areas. The porch and the small tower over the entrance are the elements that connect the inner space to the outer space, being a transition area (Fig. 6).

\footnotetext{
${ }^{9}$ Stănculescu FL., Gheorghiu Ad., Stahl P., Petrescu P. (1957). Arhitectura populară românească. Regiunea Ploești. București: Editura Tehnică, p. 15-18.
} 
Acoperișul este deseori prelungit spre spatele casei și uneori și pe lateral până aproape de sol, protejând pereții casei. Spațiile obținute, denumite diferit în funcție de zonă: polată, cămară, chelar, magazie, șopron, sunt folosite pentru depozitare. ${ }^{10}$

Această structură protejează pereții casei de apa provenită din precipitații și umbresc pereții pe perioada verii, atunci când în România temperaturile maxime medii anuale se situează între $22^{\circ} \mathrm{C}$ și $24^{\circ} \mathrm{C}$ în timpul verii putând ajunge la $44.5^{\circ} \mathrm{C}$.

Streșinile sunt foarte largi astfel încât umbresc în totalitate pereții (Fig. 7) dinspre est, sud sau vest, mai ales zona cu accesul în casă. În acest mod se evită acumularea căldurii provenite direct din razele solare în pereții de pământ și, în consecință, spațiul interior rămâne răcoros în sezonul cald.

Pentru calculul dimensiunilor streșinilor se va ține cont de faptul că în țara noastră, care se află la paralela $45^{\circ}$ latitudine nordică, Soarele se va situa la meridianul locului în poziții care variază între $21^{\circ} 30^{\prime}$ în timpul solstițiului de iarnă, $68^{\circ}$ în timpul solstițiului de vară și $45^{\circ}$ la echinocții.

În unele zone ale țării învelitoarea acoperișului este realizată dintr-un strat gros de pământ și bălegar în amestec cu paie sau din stuf, materiale care contribuie semnificativ la capacitatea de izolare termică a clădirii.

Dimensiunea acoperișului este foarte importantă. În acoperișurile mari, cu panta de $45^{\circ}$, se crează un spațiu tampon față de spațiul destinat locuirii. Aerul cald din camere se ridică în volumul șarpantei, răcorindu-se astfel spațiul interior. Totodată, învelitoarea acoperișului realizată în mod tradiţional permite ventilarea continuă a podului.

\section{Amplasarea funcțiunilor după considerente energetice}

Funcțiunile spațiilor sunt amplasate în raport cu punctele cardinale. De exemplu spațiile de depozitare, chiler, cămară sunt prevăzute, în zona mai răcoroasă a casei, pe latura de nord sau nord-est. Camerele de locuit sunt amplasate către sud, sud-vest, această zona fiind încălzită de razele solare pe timpul iernii.

Vatra, principala sursă de căldură, este amplasată în centrul casei. În acest fel, în timp ce se prepară mâncarea se încălzesc și spațiile interioare alăturate. La casele mai mari cuptoarele sau sobele sunt amplasate în dreptul pereților (Fig. 8), astfel încât încălzesc câte două spații în același timp.

Toate gospodăriile tradiționale au prevăzute în incinta lor un spațiu destinat gătitului pe timpul verii. Uneori bucătăria de vară este alipită casei dar cu acces separat. De cele mai multe ori este realizată separat în incinta gospodăriei sau este prevăzut un simplu cuptor în curte, protejat cu un acoperiș ${ }^{11}$. Astfel, în timpul verii, prepararea mâncării se realizează în afara casei şi, în consecință, se evitată supraîncălzirea spațiilor interioare.

\footnotetext{
${ }^{10}$ Stănculescu FL., Gheorghiu Ad., Stahl P., Petrescu P. (1958). Arhitectura populară românească. Regiunea București. București:Editura Tehnică, p.15-20.

${ }^{11}$ Stănculescu FL., Gheorghiu Ad., Stahl P., Petrescu P. (1956). Arhitectura populară românească. Dobrogea. București:Editura Tehnică, p. 15-18.
} 
The roof of the back of the house and sometimes of one side is often extended to the ground, protecting the walls of the house. The obtained spaces are used for storage. These spaces are named differently in distinct areas (polată, cămară, chelar, magazie, șopron). ${ }^{12}$

This roof extensions protect the walls from rainfall and shades the walls during the summer, when in Romania the average annual average temperatures are between $22^{\circ} \mathrm{C}$ and $24^{\circ} \mathrm{C}$ and can reach up to $44.5^{\circ} \mathrm{C}$.

The eaves are very wide so that they completely shade the walls (Fig. 7) from the east, south or west, especially the area with the entrance. This avoids the accumulation of heat directly from the sun's rays in the walls of the earth and consequently the interior space remains cool during the warm season.

For the calculation of the dimensions of eaves one has to take into account that in our country, situated at the $45^{\circ}$ parallel north latitude, the Sun will be at the meridian of the particular place in positions that vary between $21^{\circ} 30$ 'during the winter solstice, $68^{\circ}$ during the summer solstice and $45^{\circ}$ at equinoxes.

In some areas of the country, the roof covering is made of a thick layer of soil and manure mixed with straw or reed, which contributes significantly to the thermal insulation capacity of the building.

The size of the roof is very important. In large roofs with a $45^{\circ}$ slope, a buffer space is created in relation to the living space. The warm air in the rooms rises in the volume of the roof, thus cooling the interior space. At the same time, the traditional roofing allows continuous ventilation.

\section{Distribution of functions after energy considerations}

The particular rooms are located in relation to the cardinal points. For example, storage areas are placed in the cooler area of the house on the north or northeast side. The living rooms are located south, southwest, this area being heated by sunlight in winter.

The fireplace, the main heat source, is located in the center of the house. In this way, as the food is prepared, the lateral interior spaces are heated. In larger homes, stoves are located near the walls (Fig. 8), so they heat up two spaces at the same time.

All traditional households have a special space for cooking in summer. Sometimes the summer kitchen is attached to the house but has separate entrance. In other cases, the kitchen placed separately on the plot or is a simple oven protected by a roof ${ }^{13}$. Thus, during summer, food preparation is done outside the house and, as a consequence, overheating of interior spaces is avoided.

\footnotetext{
${ }^{12}$ Stănculescu FL., Gheorghiu Ad., Stahl P., Petrescu P. (1958). Arhitectura populară românească. Regiunea București. București: Editura Tehnică, p. 15-20.

${ }^{13}$ Stănculescu FL., Gheorghiu Ad., Stahl P., Petrescu P. (1956). Arhitectura populară românească. Dobrogea. București: Editura Tehnică, p. 15-18.
} 


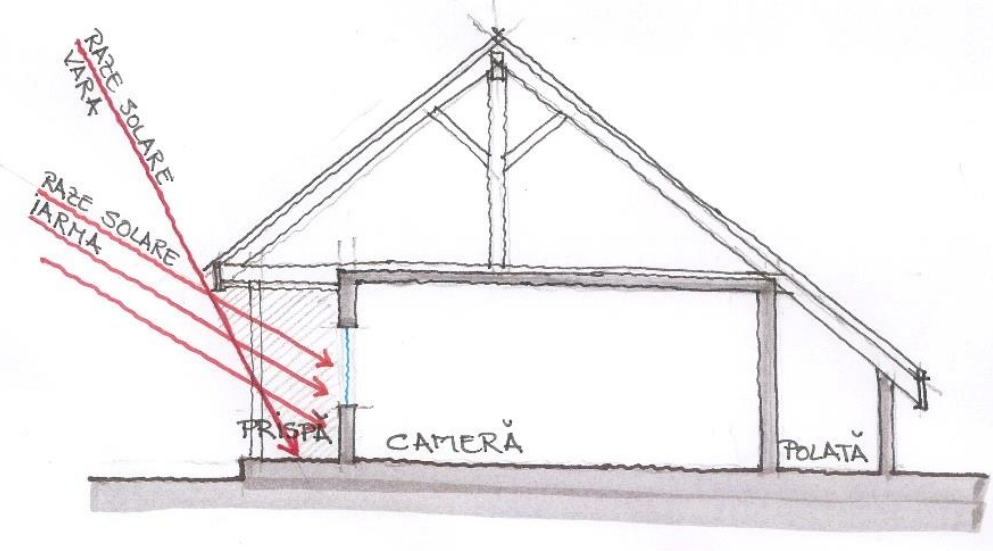

Fig. 7: Secțiune printr-o casă tradițională din pământ, cu prispă și polată. Acoperișul prelungit peste zona prispei umbrește întregul perete în timpul anotimpului cald. Iarna, razele solare încalzesc peretele casei. Section through a traditional house made with earth, with a porch (prispă) and storage room (polată). The prolonged roof over the porch shades the entire wall during summer. In the winter, the sun's rays warm the wall of the house.

\section{Concluzii}

În condițiile încălzirii globale, este esențială reducerea consumului de combustibili fosili. Prin urmare ne dorim clădiri de locuit care să fie răcoroase pe timpul verii și să mențină căldura cât mai mult în timpul iernii. În acest scop am arătat o serie de elemente ale arhitecturii populare românești care pot fi preluate și folosite în proiectare:

- Pământul folosit ca material de construire mărește performanța energetică a clădirii datorită masei termice ridicate. În funcție de orientarea față de punctele cardinale și de poziționarea zonelor vitrate se poate folosi căldura solară pentru iluminare și încălzire.

- Realizarea unor obiecte de mobilier din pământ ajută la menținerea căldurii în spațiile interioare. Căldura din sobe sau șeminee poate fi preluată printr-un sistem de canale în interiorul structurilor de pământ care acumulează căldură și o eliberează mai târziu atunci când focul va fi stins.

- Funcțiunile spațiilor interioare pot fi poziționate astfel încât spațiile destinate locuirii să beneficieze de lumina și căldură solară, iar spațiile de depozitare și anexe așezate pe partea de nord-est să rămână răcoroase în timpul verii.

- Realizarea acoperișului cu streșini largi, prispa și foișorul sunt elemente care contribuie la umbrirea pereților păstrând spațiile interioare răcoroase pe timpul verii.

- Învelitoarea acoperișului realizată dintr-un strat gros de pământ și paie sau din stuf, contribuie semnificativ la capacitatea de izolare termică a clădirii.

- Rezistenţa termică relativ mică a pământului va fi compensată prin adăugarea unui strat termoizolant din materiale care permit structurii peretelui să respire. Grosimea acestui strat variază în funcție de compoziţia materialului. 


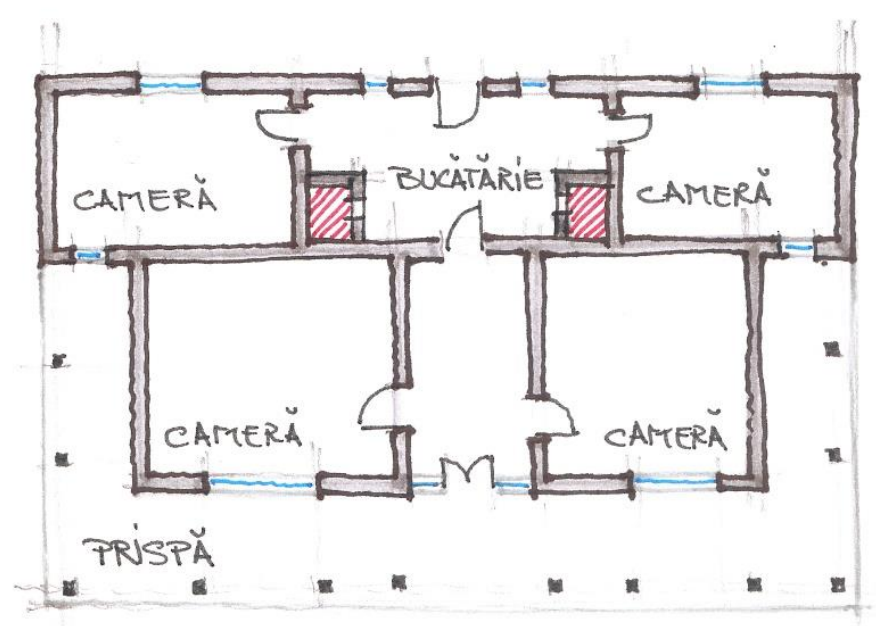

Fig. 8: Casele mai mari, cu patru camere, au sobele amplasate în centrul casei, astfel încălzind spațiile adiacente.

Larger buildings, four-room houses have the stoves placed in the center, thus warming up the adjacent spaces.

\section{Conclusions}

Considering the global warming issue, it is essential to reduce fossil fuel consumption. Therefore, we want residential buildings that are cool in the summer and keep the heat as long as possible during the winter. For this purpose we have shown a series of features of Romanian traditional architecture that can be used in modern design:

- Earth used as building material increases the energy performance of the building due to its high thermal mass. Depending on the orientation relative to the cardinal points and the positioning of the glazed areas, solar heating and lighting can be used.

- Making furniture out of clay helps keep the heat in the interior of the house. Heat from stoves or fireplaces can be taken over by a channel system inside the earth structures and released gradually even after the fire is extinguished.

- Rooms can be positioned so that living spaces benefit from light and solar heat, while storage and annexes on the northeastern side will remain cool during the summer.

- Making the roof with broad eaves and porches help shade the walls and keeping the inside cool in summer.

- A roof made of a thick layer of soil and straw or reed contributes significantly to the thermal insulation capacity of the building.

- Thermal resistance of earth constructions can be improved by adding an insulating layer that allows the structure of the wall to "breathe". The thickness of this layer varies depending on the composition of the material. 


\section{Referinţe/References}

C107/3, Normativ de calcul termotehnic al elementelor de construcţie ale clădirilor.

Ionescu, G. (1957). Arhitectura populară românească. București:Editura Tehnică.

Stănculescu FL., Gheorghiu Ad., Stahl P., Petrescu P. (1958). Arhitectura populară românească. Regiunea București. București:Editura Tehnică.

Stănculescu FL., Gheorghiu Ad., Stahl P., Petrescu P. (1956). Arhitectura populară românească. Dobrogea. București:Editura Tehnică.

Stănculescu FL., Gheorghiu Ad., Stahl P., Petrescu P. (1957). Arhitectura populară românească. Regiunea Ploești. București:Editura Tehnică.

\section{Referinţe web/Web references}

Lehmundfeuer, http://www.lehmundfeuer.de/lehmundfeuer2.0/blog/2013/01/26/bildergalerieprojekte-speicherofen/

Hajer Milena, Lehmbau-Funktion und Ästhetik Eine Besondere Lernleisung mit den Schwerpunkten Kunst / Biologie, http://milena.hajer.com/\#deutschland

Druk White Lotus School, http://www.dwls.org/sustainability/sustainable-design.html 